\title{
A Comparison of Photograph-Interpreted and IfSAR-Derived Maps of Polar Bear Denning Habitat for the 1002 Area of the Arctic National Wildlife Refuge, Alaska
}

Open-File Report 2018-1083 



\section{A Comparison of Photograph-Interpreted and IfSAR- Derived Maps of Polar Bear Denning Habitat for the 1002 Area of the Arctic National Wildlife Refuge, Alaska}

By George M. Durner and Todd C. Atwood

Open-File Report 2018-1083

U.S. Department of the Interior

U.S. Geological Survey 


\title{
U.S. Department of the Interior \\ RYAN K. ZINKE, Secretary
}

\section{U.S. Geological Survey \\ William H. Werkheiser, Deputy Director \\ exercising the authority of the Director}

\author{
U.S. Geological Survey, Reston, Virginia: 2018
}

For more information on the USGS-the Federal source for science about the Earth, its natural and living resources, natural hazards, and the environment-visit https://www.usgs.gov/ or call 1-888-ASK-USGS (1-888-275-8747).

For an overview of USGS information products, including maps, imagery, and publications, visit https://store.usgs.gov/.

Any use of trade, firm, or product names is for descriptive purposes only and does not imply endorsement by the U.S. Government.

Although this information product, for the most part, is in the public domain, it also may contain copyrighted materials as noted in the text. Permission to reproduce copyrighted items must be secured from the copyright owner.

Suggested citation:

Durner, G.M., and Atwood, T.C., 2018, A comparison of photograph-interpreted and IfSAR-derived maps of polar bear denning habitat for the 1002 Area of the Arctic National Wildlife Refuge, Alaska: U.S. Geological Survey Open-File Report 2018-1083, 12 p., https://doi.org/10.3133/ofr20181083.

ISSN 2331-1258 (online) 


\section{Contents}

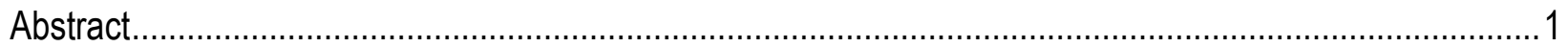

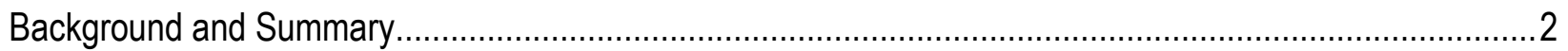

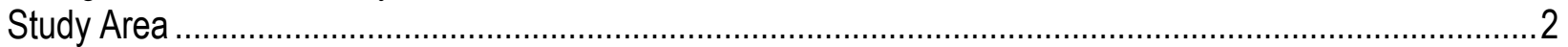

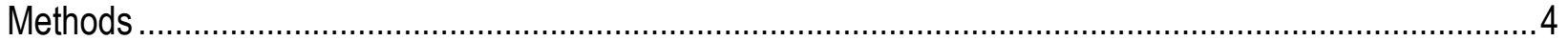

IfSAR-Derived Maternal Denning Habitat ....................................................................................... 4

Photograph-Interpreted Maternal Denning Habitat ........................................................................... 5

Comparing Photograph-Interpreted Denning Habitat to IfSAR-Derived Denning Habitat ...........................

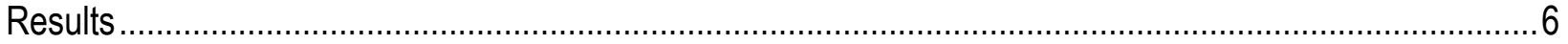

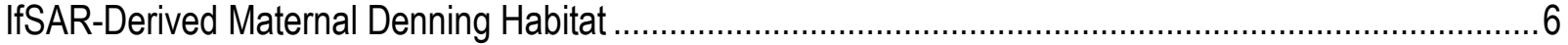

Photograph-Interpreted Maternal Denning Habitat ........................................................................

Comparison of Photograph-Interpreted Denning Habitat to IfSAR-Derived Denning Habitat .....................6

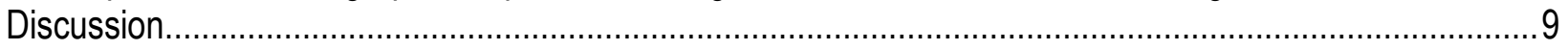

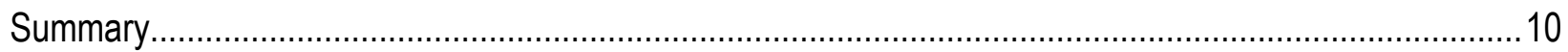

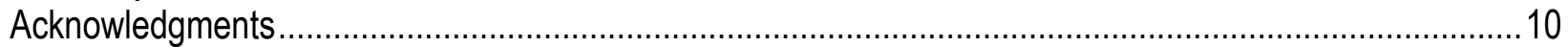

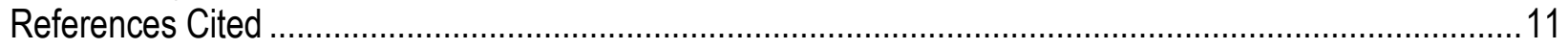

\section{Figures}

Figure 1. Map showing the 1002 Area of the Arctic National Wildlife Refuge, Alaska, including the extent of IfSAR data (that is, IfSAR tiles) used in this report

Figure 2. Distance between IfSAR-derived maternal denning habitat polygons $(n=152,503)$ and random locations $(n=152,503)$ within the 1002 Area of the Arctic National Wildlife Refuge, to photograph-interpreted maternal denning habitat lines $(n=4,458)$

Figure 3. Comparisons of photograph-interpreted and IfSAR-derived polar bear maternal denning habitat in the 1002 Area of the Arctic National Wildlife Refuge, Alaska

\section{Table}

Table 1. Projection data for the IfSAR digital terrain models used for estimating polar bear maternal denning habitat in the Arctic National Wildlife Refuge 1002 Area 


\section{Conversion Factors}

International System of Units to U.S. customary units

\begin{tabular}{lll}
\hline \multicolumn{1}{c}{ Multiply } & By & \multicolumn{1}{c}{ To obtain } \\
\hline centimeter $(\mathrm{cm})$ & Length & \\
meter $(\mathrm{m})$ & 0.3937 & inch (in.) \\
kilometer $(\mathrm{km})$ & 3.281 & foot $(\mathrm{ft})$ \\
\hline & 0.6214 & mile $(\mathrm{mi})$ \\
\hline hectare (ha) & Area & \\
square kilometer $\left(\mathrm{km}^{2}\right)$ & 2.471 & acre \\
hectare (ha) & 247.1 & acre \\
square kilometer $\left(\mathrm{km}^{2}\right)$ & 0.003861 & square mile $\left(\mathrm{mi}^{2}\right)$ \\
\hline
\end{tabular}

Temperature in degrees Celsius $\left({ }^{\circ} \mathrm{C}\right)$ may be converted to degrees Fahrenheit $\left({ }^{\circ} \mathrm{F}\right)$ as follows:

$$
{ }^{\circ} \mathrm{F}=\left(1.8 \times{ }^{\circ} \mathrm{C}\right)+32 .
$$

\section{Abbreviations}

ANILCA Alaska National Interests Land Conservation Act

ANWR Arctic National Wildlife Refuge

DOI U.S. Department of the Interior

DSM digital surface model

DTM digital terrain model

IfSAR interferometric synthetic aperture radar

NPRA National Petroleum Reserve-Alaska

RMSE root mean square error

USGS U.S. Geological Survey 


\title{
A Comparison of Photograph-Interpreted and IfSAR- Derived Maps of Polar Bear Denning Habitat for the 1002 Area of the Arctic National Wildlife Refuge, Alaska
}

\author{
By George M. Durner and Todd C. Atwood
}

\begin{abstract}
Polar bears (Ursus maritimus) in Alaska use the Arctic National Wildlife Refuge (ANWR) for maternal denning. Pregnant bears den in snow banks for more than 3 months in winter during which they give birth to and nurture young. Denning is one of the most vulnerable times in polar bear life history as the family group cannot simply walk away from a disturbance without jeopardizing survival of newly born cubs. The ANWR includes the "1002 Area", a region recently opened for oil and gas exploration by the U.S. Department of the Interior (DOI). As a part of its mission, the DOI “... protects and manages the Nation's natural resources ..." and is therefore responsible for conserving polar bears and encouraging development of energy potential. Because future industrial activities could overlap habitats used by denning polar bears, identifying these habitats can inform the decisions of resource managers tasked to develop resources and protect polar bears. To help inform these efforts, we qualitatively compared the distribution of denning habitat identified by two different methods: previously published habitat from manual interpretation of aerial photographs, and habitat derived by computer interrogation of interferometric synthetic aperture radar (IfSAR) digital terrain models (DTM). Because photograph-interpreted methods depicted denning habitat as a line and IfSAR-derived methods depicted habitat as a polygon, we assessed agreement between the two methods with distance measurements. We found that 77.5 percent of IfSAR-derived denning habitat $\left(79.6 \mathrm{~km}^{2} ; 1.2\right.$ percent of the $6,837.0 \mathrm{~km}^{2} 1002$ Area) was within $600 \mathrm{~m}$ of photograph-interpreted habitat $(3,026.9 \mathrm{~km})$, including 53.9 percent within $200 \mathrm{~m}$. This distribution differed from that of randomly distributed points, as only 49.4 percent of these occurred within $600 \mathrm{~m}$ of photograph-interpreted habitat, including 18.3 percent within $200 \mathrm{~m}$. Both methods appear to identify the major physiographic features that polar bears might select for denning. IfSAR-derived methods identified habitat at greater frequency beyond major landscape features such as coastal bluffs, river banks and lakeshores, were more likely to identify isolated pockets of putative denning habitat, and were easier to implement than deriving habitat from photograph-interpretive efforts. However, previous research suggests that photograph-interpretation methods may identify denning habitat more correctly than computer interrogation of IfSAR DTMs. Future work should quantify the distribution of IfSAR-derived denning habitat relative to actual landscape features and polar bear maternal dens in the 1002 Area, and investigate the feasibility of habitat identification from finer grained DTMs.
\end{abstract}




\section{Background and Summary}

Historically, most polar bears (Ursus maritimus) from the Southern Beaufort Sea subpopulation constructed maternity dens on the sea ice. However, over the last three decades, there has been a landward shift in the distribution of dens, with most now occurring on land (Fischbach and others, 2007; Olson and others, 2017). Based on data collected from radio-tagged adult female bears, maternal denning now occurs at relatively high densities along the central and eastern Arctic coastal plain of Alaska (Pearce and others, 2018). The availability of denning habitat-mediated by landscape features that facilitate the formation of snow drifts-appears to increase in the eastern part of the coastal plain (Durner and others, 2001, 2006).

Durner and others (2006) used manual interpretation of high-resolution aerial photographs to identify 3,621 km of linear denning habitat within a 7,994 $\mathrm{km}^{2}$ area of the Arctic National Wildlife Refuge (ANWR), which is situated in the eastern side of the Arctic coastal plain. Durner and others (2006) determined that mapped denning habitats in the ANWR were widely distributed and occurred along the coast and inland to the Brooks Range, including part of the coastal plain known as the 1002 Area. Congress created the ANWR under the Alaska National Interests Land Conservation Act (ANILCA) of 1980. Section 1002 of ANILCA designated an area of the coastal plain (that is, the 1002 Area) for potential oil and gas exploration and development.

In December 2017, Federal legislation (that is, Public Law 115-97) was passed that included a provision to open the 1002 Area to oil and gas exploration and eventual extraction. As a result, there is renewed interest in estimating the amount and distribution of polar bear maternal denning habitat in the 1002 Area, as a step toward better understanding environmental and biological characteristics of important polar bear habitats in the ANWR. No evaluation of denning habitat in ANWR has occurred since that described in Durner and others (2006), despite potential improvements in mapping methodologies (for example, Durner and others, 2013). Herein, we describe an analysis done to qualitatively compare maps of maternal denning habitat constructed using manual interpretation of highresolution color aerial photographs (as described in Durner and others, 2006) and computer interrogation of radar-derived digital terrain models (as described in Durner and others, 2013).

\section{Study Area}

The ANWR is the largest and northernmost wildlife refuge in the United States, encompassing 7.9 million hectares. The 1002 Area is a 0.6 million ha region on the coastal plain of the ANWR that lies north of the Brooks Range and south of the Beaufort Sea, with an eastern boundary of the Aichilik River and a western boundary of the Canning River (fig. 1) (Jorgenson and others, 2002). Sixteen landcover classes have been mapped within the ANWR, with moist sedge-tussock tundra, moist sedge-dryas tundra, wet graminoid tundra, and moist sedge-willow tundra being among the most common land classes in the 1002 Area (Douglas and others, 2002). 
Pearce and others (2018) described how climate conditions of the greater 1002 Area have changed over the last four decades. Jorgenson and others (2015) stated that the mean annual temperature at the Kuparuk weather station, $190 \mathrm{~km}$ west of the 1002 Area, increased by $2.5^{\circ} \mathrm{C}$ between 1984 and 2009 (Western Regional Climate Center, 2010). Regional marine climate conditions also have changed. For example, warmer air temperatures have been accompanied by rising near-surface sea water temperatures along the coast, which increased by $1.0-1.5^{\circ} \mathrm{C}$ during $2007-2011$ relative to the 1982 2011 long-term mean (Johannessen and others, 2004; Stroeve and others, 2014). Warmer air and ocean temperatures have altered sea ice extent and phenology, causing the annual number of days that the southern Beaufort Sea was covered by ice to decrease at a rate of -17.5 days per decade from 1979 to 2014 (Stern and Laidre, 2016). Since the late 1990s, the mean duration of the open-water season (that is, period of time when sea ice is largely absent from the biologically productive continental shelf) has increased by 36 days (Atwood and others, 2016).

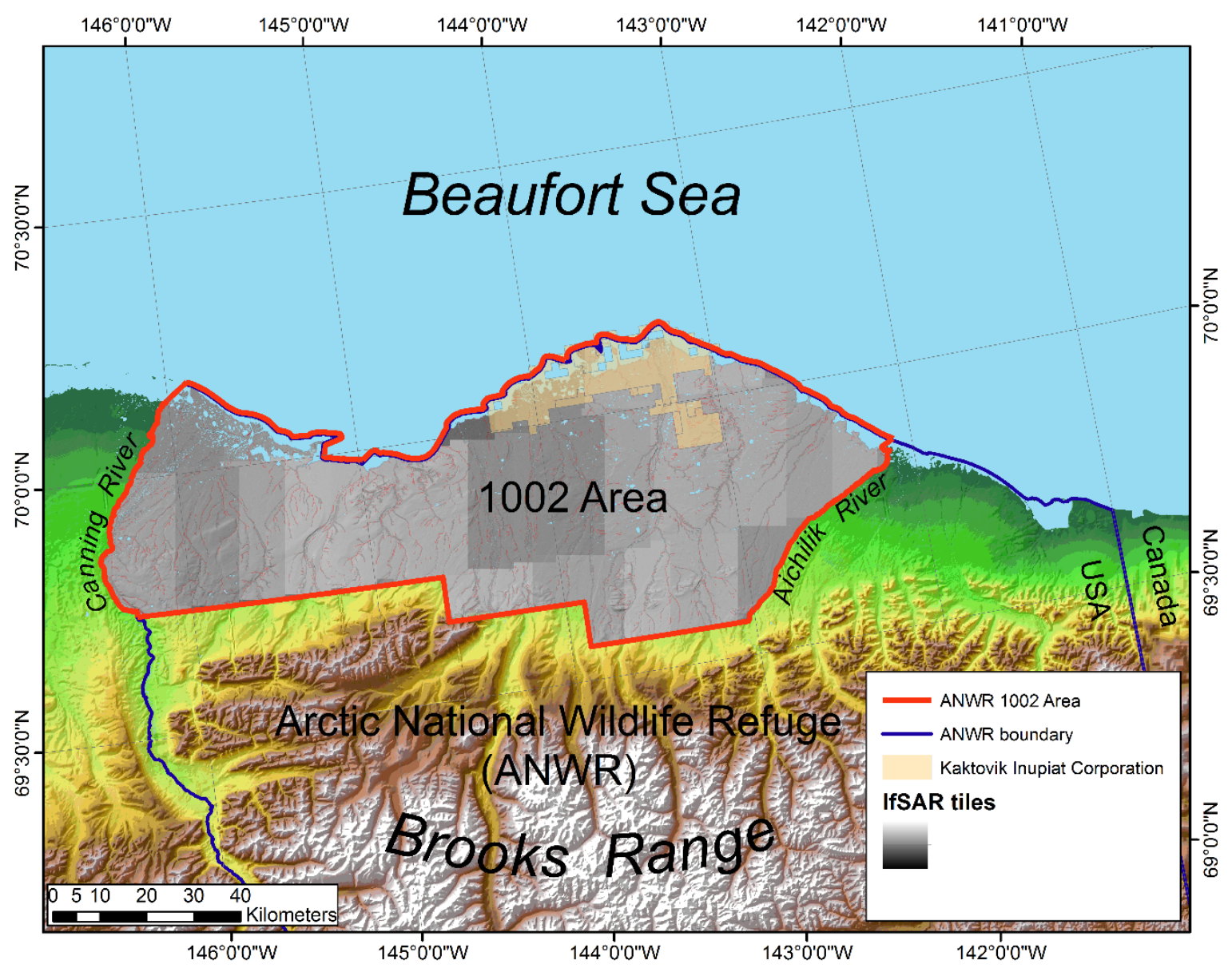

Figure 1. Map showing 1002 Area of the Arctic National Wildlife Refuge, Alaska, including the extent of IfSAR data (that is, IfSAR tiles) used in this report. 


\section{Methods}

The boundaries of the 1002 Area were obtained as a geographic information system (GIS) shapefile (ESRI, Redlands, California) from the U.S. Fish and Wildlife Service, Region 7, Realty and Natural Resources GIS data page (https://www.fws.gov/alaska/nwr/realty/data.htm; accessed December 21, 2017). We determined that the northern boundary of the original 1002 Area GIS data excluded parts of barrier islands when overlaid on interferometric synthetic aperture radar (IfSAR) digital terrain models. To ensure that all lands within the east, west, and southern boundaries of the 1002 Area were included in our analysis, we extended the northern boundary $500 \mathrm{~m}$ seaward. This modified 1002 Area became the study area used in subsequent analyses and includes all coastal barrier islands, nearshore marine waters and the area of the Kaktovik Inupiat Corporation (fig. 1).

\section{IfSAR-Derived Maternal Denning Habitat}

A digital terrain model (DTM) derived from IfSAR elevation data was used to construct a map of denning habitat for comparison to the photograph-interpreted map described in Durner and others (2006). IfSAR data for the 1002 Area of the ANWR (fig. 1) were collected by Intermap Technologies during July-August 2016 with the Intermap STAR-3i ${ }^{\circledR}$ airborne IfSAR system (Intermap, 2016) and processed into a digital surface model (DSM). The DSM had a horizontal cell dimension of $5 \times 5 \mathrm{~m}$ (1.25 m root mean square error, or RMSE) and a vertical cell resolution of $0.01 \mathrm{~m}$ (1.0 m RMSE; Nolan and Prokein, 2003; Intermap, 2016). The DSM was composed of overlapping $15 \times 15$ minute (latitude $\times$ longitude) tiles in UTM projection. Intermap Technologies converted the DSM into a DTM by removing buildings and vegetation so that the final elevation data represented a closer approximation to the true surface of Earth. DTM projection information is provided in table 1.

Table 1. Projection data for the IfSAR digital terrain models used for estimating polar bear maternal denning habitat in the Arctic National Wildlife Refuge 1002 Area.

\begin{tabular}{|l|l|}
\hline Projection & Albers \\
\hline Datum & NAD83 \\
\hline Units & meters \\
\hline 1st standard parallel & 5500.00 (degrees minutes seconds) \\
\hline 2nd standard parallel & 6500.00 (degrees minutes seconds) \\
\hline central meridian & -15400.00 (degrees minutes seconds) \\
\hline false easting (meters) & 0.0 \\
\hline false northing (meters) & 0.0 \\
\hline
\end{tabular}


The procedures of Durner and others (2013) were followed and GIS tools were used to identify individual pixels from the DTM that had an elevation difference of greater than or equal to $1.0 \mathrm{~m}$ between the focal pixel and all surrounding pixels within a $3 \times 3$ neighborhood. Pixels meeting this criterion were deemed sufficient to facilitate the accumulation of drifting snow to allow polar bears to den (that is, polar bear maternal denning habitat). Identified pixels were converted into an ESRI polygon coverage. No field measurements were available with which to assess the ability of IfSAR to identify polar bear maternal denning habitat correctly in the 1002 Area. However, Durner and others (2013) determined that similar methods used on IfSAR data in the National Petroleum Reserve-Alaska correctly identified 82 percent of denning habitat.

\section{Photograph-Interpreted Maternal Denning Habitat}

An ESRI line coverage of features depicting putative linear maternal denning habitat was created from photograph-interpretation methods for the ANWR coastal plain (Durner and others, 2006; obtained from https://alaska.usgs.gov/science/biology/polar_bears/products.html, accessed January 2018). Denning habitat was derived by manual interpretation of high-resolution aerial photographs (scale: 1 centimeter $(\mathrm{cm})=178.6 \mathrm{~m}$ ), which were subsequently digitized (Durner and others, 2001). The final denning habitat map was ground-truthed with 127 survey transects that radiated west, south, and east from the general vicinity of Barter Island (see Durner and others, 2006, fig. 1). Additionally, 38 polar bear dens located in years prior to the mapping effort were used as a qualitative check of mapped habitat. The photograph-interpreted denning habitat map was in agreement with the distribution of 84 percent (32) of the 38 known dens and 91.5 percent of denning habitat measured in the field (Durner and others, 2006).

\section{Comparing Photograph-Interpreted Denning Habitat to IfSAR-Derived Denning Habitat}

Durner and others (2001) determined that the distance between mapped denning habitat and the actual features on the ground averaged $32.0 \mathrm{~m}$ (standard deviation: $\pm 29.2 \mathrm{~m}$ ). Ground-truthing of IfSAR-derived denning habitat on the 1002 Area has not been done; hence, a similar estimate of spatial error was not possible. Therefore, we limited the horizontal error for IfSAR pixels to $1.25 \mathrm{~m}$ RMSE (Intermap, 2016). Because photograph-interpreted denning habitat was composed of lines, it was not possible to estimate the actual area of the habitat to directly compare to IfSAR-derived habitat (composed of polygons). As a result, we compared proximity of features between the two methods instead of area of overlap. We assumed that IfSAR habitat less than or equal to $62.45 \mathrm{~m}$ from photograph-interpreted habitat implied agreement between the two methods. This assumption accommodated most human error in drafting the original lines that delineated denning habitat, potential errors in 1:63,360 topographical maps used (Durner and others, 2006), and the estimated horizontal error of IfSAR pixels (Intermap, 2016). GIS distance tools were used to measure the proximity of features derived from the two methods. Differences were qualitatively compared as a histogram with frequencies by $200 \mathrm{~m}$ distance bins.

The resulting large abundance of IfSAR denning habitat polygons (see section, "Results") suggested that the distribution of IfSAR-derived habitat could reflect a uniform distribution across the 1002 Area. To compare the actual distribution of IfSAR habitat to a uniform distribution, we used randomly distributed points as a proxy of denning habitat across the landscape. Then the proximity between random points and photograph-interpreted habitat was measured and this distribution was qualitatively compared as a histogram with frequencies by $200 \mathrm{~m}$ distance bins overlaid on IfSAR distance bins. 


\section{Results}

The original study area as defined by U.S. Fish and Wildlife Service, Region 7, was $6,741.1 \mathrm{~km}^{2}$ for the 1002 Area and $0.55 \mathrm{~km}^{2}$ for the village of Kaktovik. After applying a $500 \mathrm{~m}$ seaward extension to the northern border, the entire study area, including marine waters within the $500 \mathrm{~m}$ seaward extension, was $6,837.0 \mathrm{~km}^{2}$.

\section{IfSAR-Derived Maternal Denning Habitat}

A total of 152,503 unique polygons comprising $79.6 \mathrm{~km}^{2}$ of polar bear maternal denning habitat were derived from the interrogation of the IfSAR DTM. This represented 1.2 percent of the $6,837.0 \mathrm{~km}^{2}$ 1002 Area.

\section{Photograph-Interpreted Maternal Denning Habitat}

The total length of photograph-interpreted denning habitat within the 1002 Area was 3,026.9 $\mathrm{km}$. Durner and others (2006) found the distribution of photograph-interpreted denning habitat was uniform throughout the coastal plain of the ANWR.

\section{Comparison of Photograph-Interpreted Denning Habitat to IfSAR-Derived Denning Habitat}

The distribution of IfSAR-derived denning habitat polygons generally occurred in close proximity to photograph-interpreted linear denning habitat (fig. 2). Distance measures between IfSARderived and photograph-interpreted denning habitat showed that 82,201 IfSAR polygons (53.9 percent) occurred within $200 \mathrm{~m}$ of photograph-interpreted linear denning habitat, including 17,654 IfSAR polygons (11.6 percent) within the assumed $62.45 \mathrm{~m}$ mapping error. Area within $600 \mathrm{~m}$ of photographinterpreted habitat included 118,260 (77.5 percent) IfSAR polygons (fig. 2). This distribution differs from that of 152,503 locations distributed randomly within the 1002 Area. For random locations, 28,156 (18.3 percent) were within $200 \mathrm{~m}$ of photograph-interpreted habitat and 75,296 (49.4 percent) were within $600 \mathrm{~m}$ (fig. 2). Hence, IfSAR-derived habitat was spatially distributed closer to photographinterpreted habitat than could be expected by chance. Whereas photograph-interpreted habitat generally followed linear landscape features that could be recognized by the cartographer drafting the habitat maps, IfSAR-derived habitat also included discontinuous, finer-scale landscape features, demonstrating the ability of computer processing to capture isolated pockets of suitable habitat that were not recognized in manual interpretation of aerial photographs (fig. 3). 


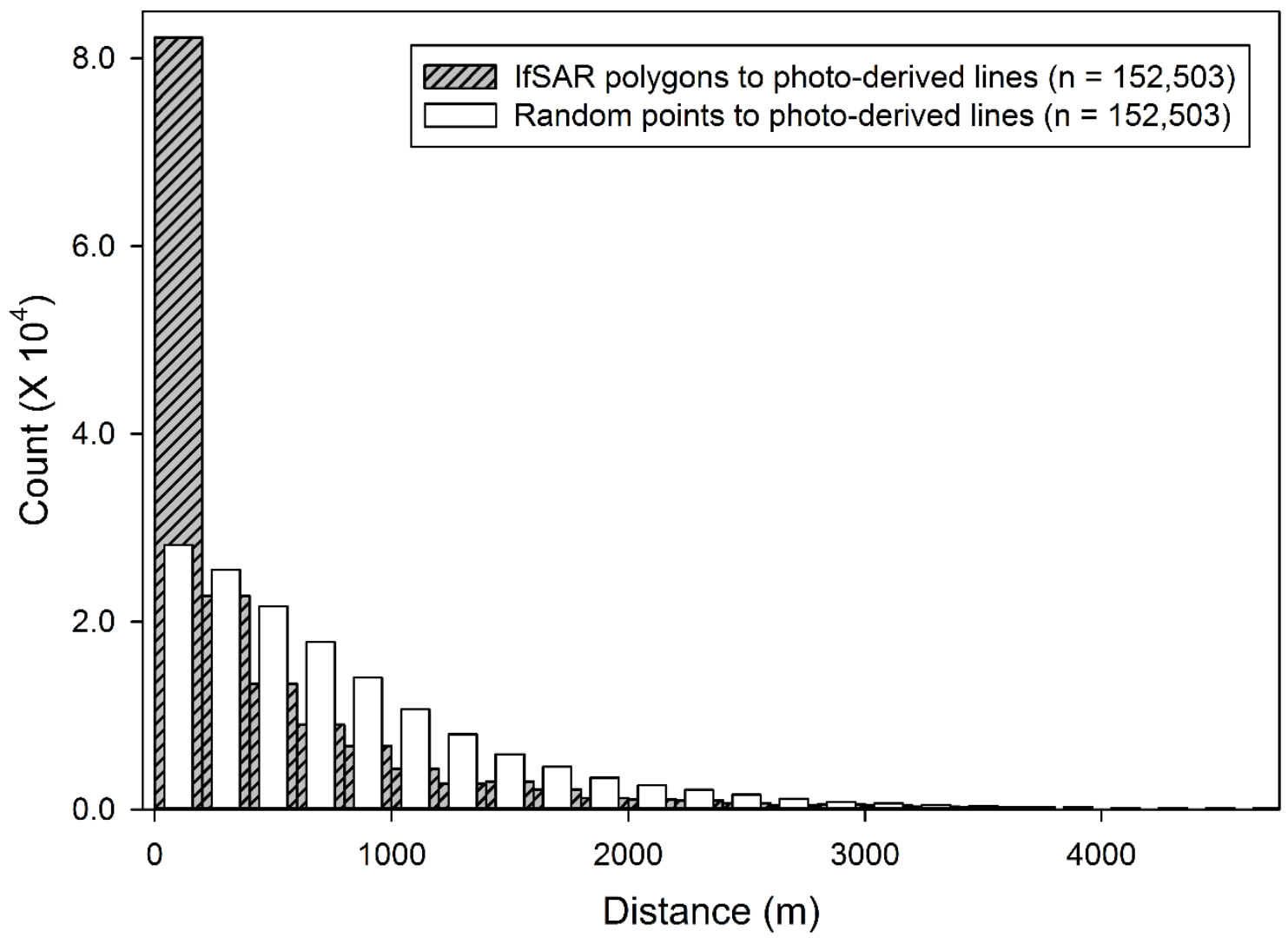

Figure 2. Distance between IfSAR-derived maternal denning habitat polygons $(n=152,503)$ and random locations $(n=152,503)$ within the 1002 Area of the Arctic National Wildlife Refuge, to photograph-interpreted maternal denning habitat lines $(n=4,458)$. Bins are centered within $200 \mathrm{~m}$ intervals. The comparison suggests a high level of spatial agreement between polar bear denning habitats derived with IfSAR (polygons) and habitat derived from photograph-interpretation (lines), and that IfSAR-derived habitat is not uniformly distributed. The $\mathrm{x}$-axis has been truncated to 4,750 meters $(\mathrm{m})$. 


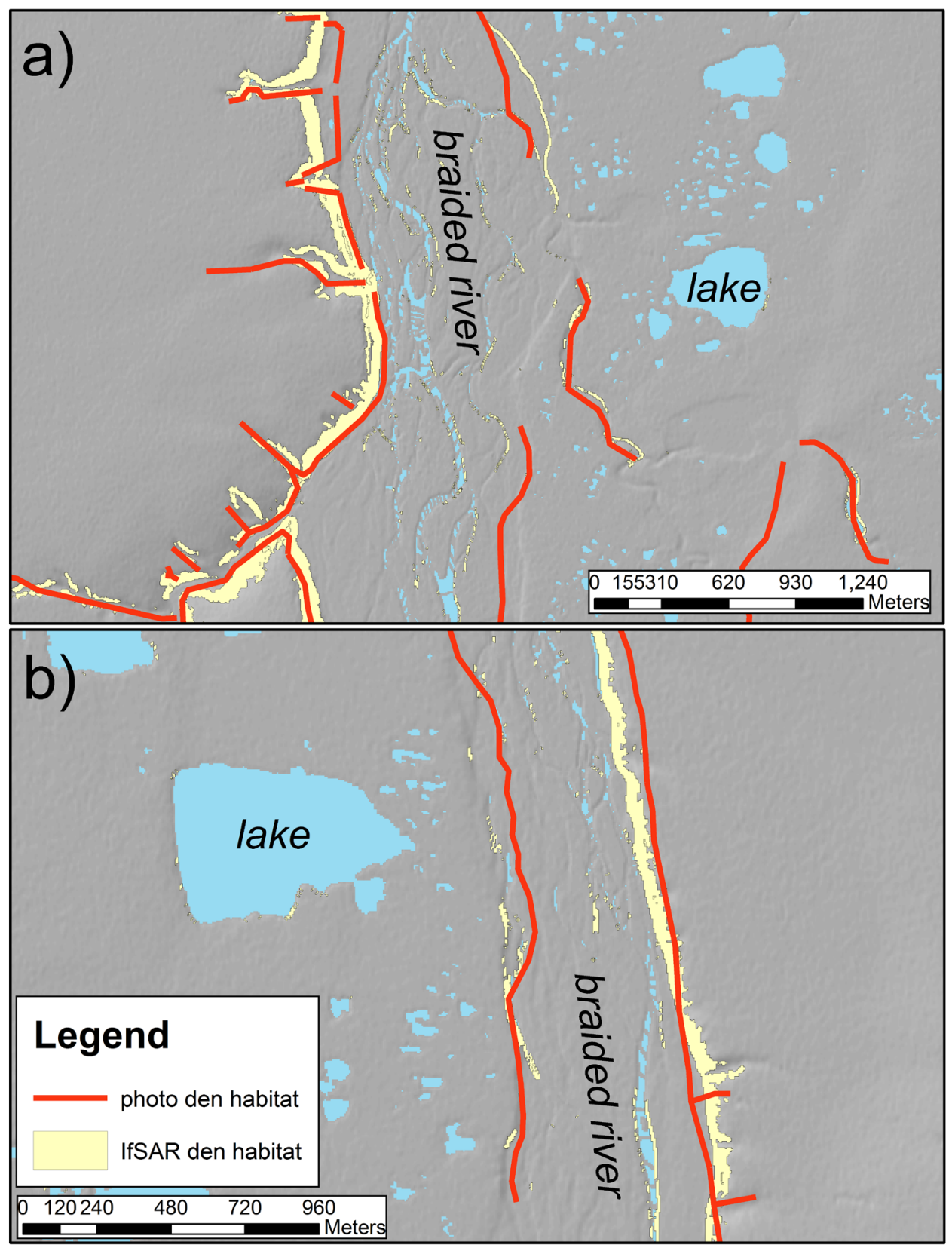

Figure 3. Comparisons of photograph-interpreted and IfSAR-derived polar bear maternal denning habitat in the 1002 Area of the Arctic National Wildlife Refuge, Alaska. Photograph-interpreted habitat followed large and easily identified terrain features identified on aerial photographs. IfSAR-derived habitat identified landscape nuances including isolated pockets of suitable habitat. (Note delineated habitat on lakeshores and in braided rivers). 


\section{Discussion}

The qualitative comparison of IfSAR-derived and photograph-interpreted maps indicated that differences exist in the ability of the two methods to identify the same maternal denning habitat in the ANWR. Terrain features suitable for denning habitat in the ANWR mostly include large segments of the coast and river- and streambanks (Durner and others, 2006) and denning habitat identified by both mapping methods consisted mostly of those features.

It is important to reiterate that the two methods were not easily comparable due to the previously mentioned differences in the initial formats of the respective datasets. IfSAR-derived denning habitat was formatted as polygons, which allowed the areal estimation of denning habitat. Photographinterpreted denning habitat was formatted as lines, allowing the linear estimation of denning habitat. Therefore, only an indirect comparison (proximity) between these two methods is possible. Although we attempted to account for the potential spatial error when assessing agreement between the two methods, we note that, unlike photograph-interpreted habitat, we lacked a similar field error estimate for IfSAR-derived habitat. Therefore, we can reasonably expect that the spatial error we used (that is, 62.45 m) would have been larger if we had verified IfSAR denning habitat in the field. This could have suggested greater agreement between the two methods, by virtue of a larger spatial error. Hence, the results presented in this report are conservative.

Despite what appears to be a large discrepancy in the distribution of photograph-interpreted lines and IfSAR-derived polygons, non-overlapping features from each method often were in close proximity. For example, photograph-interpreted habitat often bordered the large banks on both sides of braided rivers and small pockets of IfSAR-derived habitat within the river corridor (fig. 3). More than 77 percent of IfSAR-derived habitat was less than $600 \mathrm{~m}$ from photograph-interpreted maternal denning habitat and our comparison to distances from randomly derived locations suggests the observed distribution was a function of habitat and not chance. Both photograph- and IfSAR-derived habitats capture the major physiographic features that polar bears may select for denning.

Durner and others (2013) determined that an IfSAR-derived DTM used to map maternal denning habitat for the National Petroleum Reserve-Alaska (NPRA) had a greater omission error rate (18 percent) than photograph-interpreted methods (8.5 percent) used for the ANWR (Durner and others, 2006). Durner and others (2013) suggested two reasons why a greater omission error could be expected from analysis of IfSAR data. First and probably most important, the $5 \times 5 \mathrm{~m}$ pixel size of IfSAR imagery may preclude its ability to resolve very-fine scale landscape features suitable as maternal denning habitat. Of polar bear maternal den chambers (that is, the cavity where the adult and her cubs will spend the winter) measured in the field, the maximum width was $190 \mathrm{~cm}$ and there was an average of $72 \mathrm{~cm}$ of snow between the interior of the den and the environment (Durner and others, 2003). Assuming that dens have a circular area (radius $95+72 \mathrm{~cm}$ ), the footprint of a polar bear den could be $8.76 \mathrm{~m}^{2}$. This is a magnitude smaller than the area of an IfSAR pixel $\left(25 \mathrm{~m}^{2}\right)$. Hence, landscape features suitable for accumulating snow sufficient for denning are sometimes not detected by IfSAR sensors or identified by subsequent processing of IfSAR data. Second, vertical accuracy could influence the outcome. Although the vertical resolution of the native DSM was $0.01 \mathrm{~m}$, independent estimation of the vertical accuracy was greater than or equal to $0.46 \mathrm{~m}$ RMSE (Mercuri and others, 2006). This means that differences as small as $1 \mathrm{~cm}$ between IfSAR data and the true landscape could make the difference 
between a cell classified as denning habitat or not. Altering the minimum threshold elevation difference (that is, less than $1.0 \mathrm{~m}$ ) between neighboring IfSAR pixels will reduce the omission error rate for identifying denning habitat (Durner and others, 2013). However, by reducing the threshold for IfSAR pixel capture the error rate for false positive denning habitat will also increase, causing the method to identify more polygons of denning habitat than actually occurs on the landscape. Durner and others (2013) estimated a 25 percent error rate for false positives when the selection threshold was set at $1.0 \mathrm{~m}$, compared to an approximately 10 percent error rate for false positives when the selection threshold was $1.3 \mathrm{~m}$.

Both IfSAR-derived and photograph-interpretation methods for identifying potential polar bear maternal denning habitat similarly identify major landscape features. Manual photograph-interpretive methods appeared to correctly identify 95.5 percent of denning habitat (Durner and others, 2006). Because field verification is lacking within the 1002 Area for IfSAR-derived habitat we were not able to make a similar assessment, but correct identification is likely lower (that is, near 82 percent; Durner and others, 2013). Photograph-interpretive cartography methods are labor-intensive, so reassessing habitat is costly and does not lend itself to adjusting thresholds. For example, once photograph-interpreted denning habitat is identified it is not known whether the denning habitat is 1 or $5 \mathrm{~m}$ in height. In contrast, IfSAR elevation data provide a relatively cost-effective (after initial collection), flexible and repeatable means for identifying most polar bear maternal denning habitat within a region. Previous work (Durner and others, 2013) and this report suggests that IfSAR data have limitations that may be surmounted with DTMs whose pixel size is reduced to that of the average footprint of a typical polar bear maternal den.

\section{Summary}

We qualitatively compared two methods for identifying polar bear maternal denning habitat in the ANWR 1002 Area. We determined that manual photograph-interpretive methods and computer processing of IfSAR DTMs produce similar estimates on the distribution of denning habitat.

Differences exists between the two methods in their ease of execution, their output, and the accuracy of output relative to actual landscape features. Future investigations should ground-truth IfSAR-derived denning habitat to quantify precision and omission of actual polar bear maternal denning habitat on the ANWR 1002 Area.

\section{Acknowledgments}

We thank S. Breck, D. Grillo, and H. Johnson, whose constructive review of this report led to its improvement. Data or data sources used in this report are available from the USGS (Durner and Atwood, 2018). 


\section{References Cited}

Atwood, T.C., Peacock, E., McKinney, M.A., Lillie, K., Wilson, R., Douglas, D.C., Miller, S., and Terletzky, P., 2016, Rapid environmental change drives increased land use by an Arctic marine predator: PLoS One, v. 11, no. 6, p. e0155932, [Also available at https://doi.org/10.1371/journal.pone.0155932].

Douglas, D.C., Reynolds, P.E., and Rhode, E.B., 2002, Arctic Refuge coastal plain terrestrial wildlife research summaries: U.S. Geological Survey Biological Science Report 2002-0001.

Durner, G.M., Amstrup, S.C., and Ambrosius, K.J., 2001, Remote identification of polar bear maternal den habitat in northern Alaska: Arctic, v. 54, no. 2, p. 115-121. https://doi.org/10.14430/arctic770.

Durner, G.M., Amstrup, S.C., and Ambrosius, K.J., 2006, Polar bear maternal den habitat in the Arctic National Wildlife Refuge, Alaska: Arctic, v. 59, p. 31-36.

Durner, G.M., Amstrup, S.C., and Fischbach, A.S., 2003, Habitat characteristics of polar bear terrestrial maternal den sites in northern Alaska: Arctic, v. 56, p. 55-62.

Durner, G.M., and Atwood, T.C., 2018, Data used to compare photo-interpreted and IfSAR-derived maps of polar bear denning habitat for the 1002 Area of the Arctic National Wildlife Refuge, Alaska, 2006-2016: U.S. Geological Survey data release, https://doi.org/10.5066/F7DJ5DXT.

Durner, G.M., Simac, K., and Amstrup, S.C., 2013, Mapping polar bear maternal denning habitat in the National Petroleum Reserve-Alaska with an IfSAR digital terrain model: Arctic, v. 66, no. 2, p. 197206. [Also available at https://doi.org/10.14430/arctic4291.] $</$ jrn $>$

Fischbach, A.S., Amstrup, S.C., and Douglas, D.C., 2007, Landward and eastward shift of Alaskan polar bear denning associated with recent sea ice changes: Polar Biology, v. 30, no. 11, p. 1395-1405. [Also available at https://doi.org/10.1007/s00300-007-0300-4.]

Intermap, 2016, Intermap Product Handbook \& Quick Start Guide: Edit Rules Edition, v. 4.5, 152 p. Johannessen, O.M., Bengtsson, L., Miles, M.W., Kuzmina, S.I., Semenov, V.A., Alekseev, G.V., Nagurnyi, A.P., Zakharov, V.F., Bobylev, L.P., Pettersson, L.H., Hasselmann, K., and Cattle, H.P., 2004, Arctic climate change-Observed and modelled temperature and sea-ice variability: Tellus A, Dynamic Meteorology and Oceanography, v. 56, no. 4, p. 328-341. [Also available at https://doi.org/10.3402/tellusa.v56i4.14418.]

Jorgenson, J.C., Joria, P.C., and Douglas, D.C., 2002, Land cover, sec. 2 of Douglas, D.C., Reynolds, P.E., and Rhode, E.B., eds., 2002, Arctic Refuge coastal plain terrestrial wildlife research summaries: U.S. Geological Survey Biological Science Report 2002-0001, p. 4-7.

Jorgenson, J.C., Raynolds, M.K., Reynolds, J.H., and Benson, A.-M., 2015, Twenty-five year record of changes in plant cover on tundra of northeastern Alaska: Arctic, Antarctic, and Alpine Research, v. 47, no. 4, p. 785-806, https://doi.org/10.1657/AAAR0014-097.

Mercuri, P.A., Engel, B.A., and Johannsen, C.J., 2006, Evaluation and accuracy assessment of highresolution IFSAR DEMs in low-relief areas: International Journal of Remote Sensing, v. 27, no. 13, p. 2767-2786, https://doi.org/10.1080/01431160500491716.

Nolan, M., and Prokein, P., 2003, Evaluation of a new DEM of the Putuligayuk watershed for Arctic hydrological applications, in Phillips, M., Springman, S.M., and Arenson, L.U., eds. Permafrost: Proceedings of the 8th International Permafrost Conference, July 21-25, 2003, Zurich, Switzerland, p. 833-838.

Olson, J.W., Rode, K.D., Eggett, D., Smith, T.S., Wilson, R.R., Durner, G.M., Fischbach, A., Atwood, T.C., and Douglas, D.C., 2017, Collar temperature sensor data reveal long-term patterns in southern Beaufort Sea polar bear den distribution on pack ice and land: Marine Ecology Progress Series, v. 564, p. 211-224, https://doi.org/10.3354/meps12000. 
Pearce, J.M., Flint, P.L., Atwood, T.C., Douglas, D.C., Adams, L.G., Johnson, H.E., Arthur, S.M., and Latty, C.J., 2018, A summary of recent wildlife-related research conducted on the Arctic coastal plain of the Arctic National Wildlife Refuge: U.S. Geological Survey Open-File Report 2018-1003, 27 p., https://doi.org/10.3133/ofr20181003.

Stern, H.L., and Laidre, K.L., 2016, Sea ice indicators of polar bear habitat: The Cryosphere, v. 10, no. 5, p. 2027-2041, https://doi.org/10.5194/tc-10-2027-2016.

Stroeve, J.C., Markus, T., Boisvert, L., Miller, J., and Barrett, A., 2014, Changes in Arctic melt season and implications for sea ice loss: Geophysical Research Letters, v. 41, no. 4, p. 1216-1225, https://doi.org/10.1002/2013GL058951.

Western Regional Climate Center, 2010, Recent climate in the West: Western Regional Climate Center Web site, http://www.wrcc.dri.edu. 
Publishing support provided by the U.S. Geological Survey Science Publishing Network, Tacoma Publishing Service Center

For more information concerning the research in this report, contact the Director, Alaska Science Center

U.S. Geological Survey

4230 University Drive

Anchorage, Alaska 99508

https://alaska.usgs.gov 
